\title{
TABELLA PLUMBEA TRAGURIENSIS AN EXAMPLE OF RURAL MAGIC FROM DALMATIA?*
}

\begin{abstract}
Summary: This article questions the purpose of the lead tablet from Trogir (CIL III p. 961), which is considered as a phylactery against hail. By reviewing the history of existing editions, by digital examination of new photos of the tablet, as well as by comparison with similar objects a new possible categorization of the tablet will be presented.
\end{abstract}

Key words: Tragurium, defixiones, Christian exorcism, rural magic, amulets

The Tabella plumbea Traguriensis is a lamella made of lead, measuring $125 \times 105 \mathrm{~mm}$, with two holes on the left edge ( $3 \mathrm{~mm}$ and $4 \mathrm{~mm}$ in diameter), dated to the $6^{\text {th }}$ century. The Latin text, in cursive minuscule letters, is written on both sides. It was found on a hill near Trogir (Tragurium) in 1869 by a peasant working in a field. Since 1870 it has been held in the Archaeological Museum of Zagreb (inv. no. A-17913). ${ }^{1}$ Up to now it has had 20 editions, by 16 different editors. ${ }^{2}$ The majority of them (13) based their

* I want to express my thanks to professor Daniela Urbanová (Masaryk University Brno) for giving me the initial support and an extensive amount of literature when I needed it, to professor Attilio Mastrocinque (University of Verona) who sent me his article at my request in a short period of time, to Ozren Domiter (Archaeological Museum of Zagreb) for helping me to get new photographs of the tablet and, above all, to professor Béla Adamik (Eötvös Loránd University Budapest) for giving me an opportunity to take part in the first WCLD conference and present the main ideas of this paper before a most professional and most amicable audience.

${ }^{1}$ LJUBIĆ, Š.: O jednom spomeniku rimsko-kršćanske dobe skoro nadjenom u okolici trogirskoj u Dalmaciji [On a Monument of the Romano-Christian Period Recently Found in the Area of Trogir in Dalmatia]. Viestnik Narodnoga zemaljskoga muzeja u Zagrebu (=Viestnik) 1 (1870) 147.

${ }^{2}$ Detlefsen, D. in Viestnik 1 (1870) 148-151; De Rossi, G. B. in Viestnik 1 (1870) 151-153; LuUBIĆ (n. 1) 228-230; DE RossI, G. B. in Bullettino di archeologia cristiana 2 (1871) 38-40; PREDELLI, R. in Archivio Veneto I/1 (1871) 441-444; SCHUCHARDT, C. in Zeitschrift für vergleichende Sprachwissenschaft 
editions upon photographs made in 1870 and/or upon a drawing based on the photographs. Out of the three scientists who had the opportunity to see the tablet itself, only Ljubić viewed it in a preserved state (1870 and later). Already in 1935 Barada complained about its condition and said that he "wouldn't have done much" without the photographs. In 1986 A. and J. Šašel found it illegible: Superficie nunc satis corrosa singulae litterae legi iam non possunt. However, despite physically having the tablet, Ljubić could not read it. He sent photographs to Detflesen, hoping that the professor would "disperse the darkness from the tablet by the brightness of his mind" and subsequently sent them to De Rossi. ${ }^{3}$

Apart from the original being unavailable to the few experts who could read it at the time when it was still intact, the history of the tablet's editions demonstrates another anomaly. Namely, Barada, whose reading underlies all modern editions and is closely followed by them, did not know about the edition of Wünsch (1907). ${ }^{4}$ The readings of Wünsch, which differ in several key words, do not appear in Barada's commentary, which gives various readings of the previous editors, nor is the name of Wünsch cited among Barada's predecessors. Thus, Wünsch's quite different reading, although available to modern researchers, made little impact on modern science and the editions based on Barada's text took prevalence. ${ }^{5}$ The text of both editions is as follows:

20 (1872) 300; ZANGEMEISTER K. in CIL III p. 961 nr. XXVI et add. p. 2181; DE Rossi, G. B. in Viestnik 2 (1876) 62; ZANGEMEISTER K. in Viestnik 2 (1876) 63; LJUBIĆ, Š. in Viestnik 2 (1876) 66; BARTOLI, M. G.: Das Dalmatische. Vol. 2. Wien 1906, 259; LECLERCQ, H. in Dictionnaire d'Archéologie Chrétienne et de Liturgie I/2 (1907) 1803, s.v. Amulettes; WünSCH, R.: Antike Fluchtafeln. Bonn 1907, 26-28; SKOK, P.: Pojave vulgarno-latinskoga jezika na natpisima rimske provincije Dalmacije [Features of Vulgar Latin in the Inscriptions from the Roman Province of Dalmatia]. Zagreb 1915, 99-100; DIEHL, E.: Inscriptiones Latinae Christianae veteres. Vol. I. Berlin 1925, nr. 2389; BARADA, M.: Tabella plumbea Traguriensis. Vjesnik Arheološkog muzeja u Zagrebu 16/1 (1935) 11-18; MIHĂESCU, H.: Limba latină în provinciile dunărene ale Imperiului Roman [The Latin Language in the Danubian Provinces of the Roman Empire]. Bucureşti 1960, 265 nr. 296; ŠAŠEL, A. - ŠAŠEL, J.: Inscriptiones Latinae quae in Iugoslavia inter annos MCMII et MCMXL repertae et editae sunt [Situla 25]. Ljubljana 1986, 378-383 nr. 2792; MASTROCINQUE, A.: Magia agraria nell'impero cristiano. MedAnt VII/2 (2004) 828; KAPITANOVIĆ, V.: Zaklinjanja, zapisi i svete moći u pučkoj religioznosti od antike do suvremenoga doba [Adjurations, Short Written Prayers and Relics in the Popular Religiosity from Antiquity to the Modern Age]. In Kultovi, mitovi $i$ vjerovanja u Zagori. Split 2013, 321-322.

${ }^{3}$ BARADA (n. 2) 11; ŠAŠEL-ŠAŠEL (n. 2) 378; LJUBIĆ (n. 1) 147.

4 BARADA (n. 2) 11-18.

${ }^{5}$ See ŠAŠEL-ŠAŠEL (n. 2) 378: "Textum optime lectum dat" (sc. Barada); MASTROCINQUE (n. 2) 827; Maltomini, F.: Due nuovi testi di magia rurale. Zeitschrift für Papyrologie und Epigraphik 164 (2008) 172; KAPITANOVIĆ (n. 2) 321-322. 


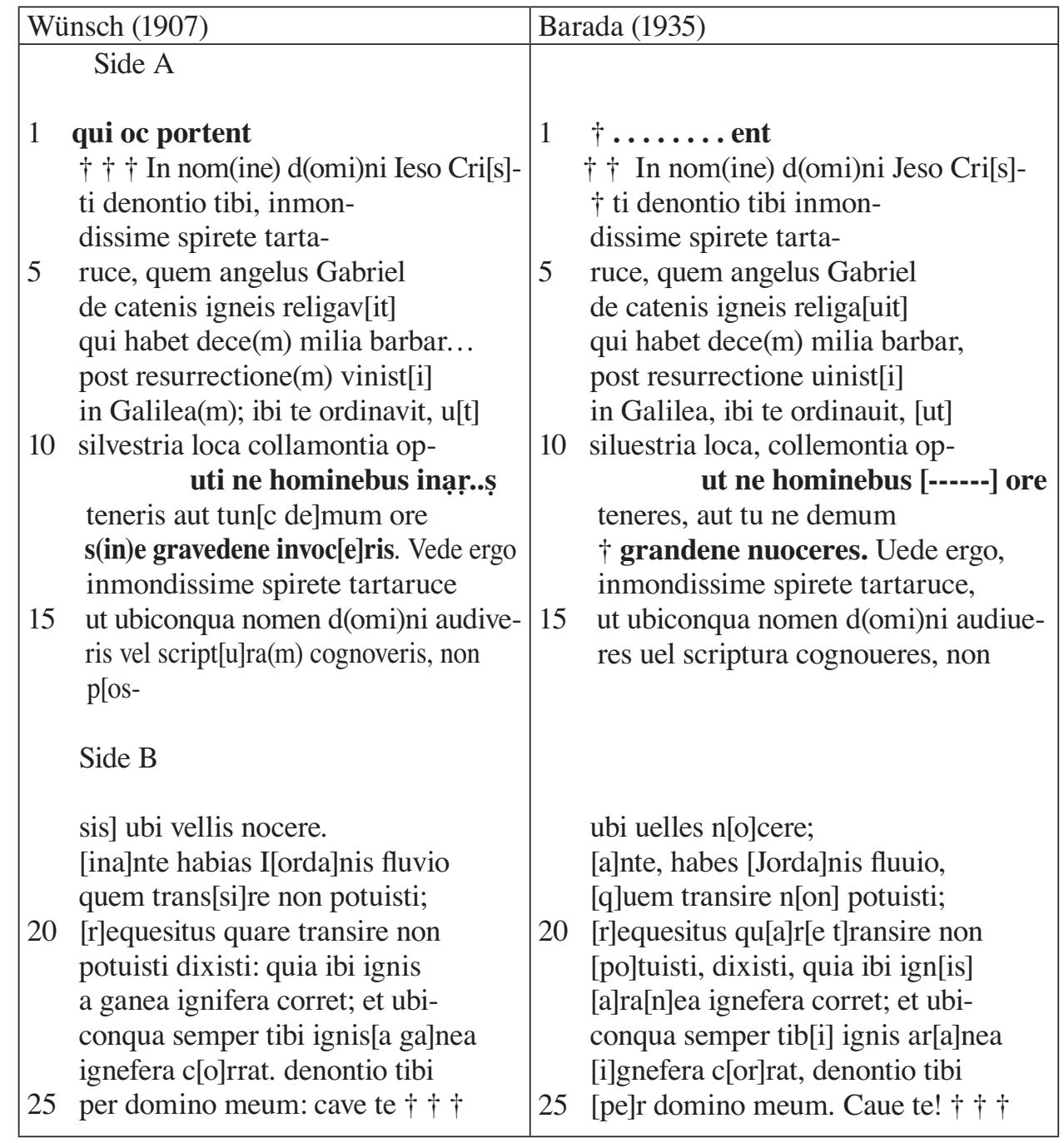

\section{TWO DIFFERENT EDITIONS}

The text in both versions is almost identical in most parts: an exorcistic formula in the first person singular addressed directly to the demon (denontio tibi $\mathbf{2 - 5}, \mathbf{2 4 - 2 5}$ ) and three apocryphal stories historiolae which depict the demon defeated in different ways (chained with burning fetters 5-7, banished to wild mountainous places 8-12, stopped by the River Jordan 18-24), as well as lines 14-17. The differences which present the reading of Wünsch here are minor and do not greatly change the sense of the sentences: they offer either different spellings collamontia/collemontia $\mathbf{1 0}$, ignifera/ignefera $\mathbf{2 2}$, 
or a different reading of an adjective a ganea/aranea $\mathbf{2 2 , 2 3}$ or at the most, a different verb mood habias/habes $\mathbf{1 8}$.

However, lines 1, 11-13 show differences that could affect the sense of the sentence. Namely, according to Wünsch the continuation of the half-line 11, which is written in smaller letters and obviously was added later between the lines, is line $\mathbf{1}$, written on the upper edge of the lamella. Together these $(\mathbf{1 1 + 1})$ represent a part of the clause which should be inserted in line 12, after-teneris. The original text should have had the following order: uti ne hominebus inar..s/ qui oc portent/ aut tun[c de]mum orel $s($ in)e gravedene invoc[e]ris. After proposing two possible reconstructions of inar..s incurras and invadas, Wünsch in his commentary explains the two half-lines (11+1) read together: "the one who wears this amulet is freed from any incursion of the devil". (He was of an opinion that the two holes were used to put a thread through and that the lamella was worn around the neck.)

Further on, by recognizing ore for horae, Wünsch translates lines 12-13 in the following way: "from this hour the evil spirit can be invoked without any difficulty" (sc. by a magician who invokes the evil spirit in his daily business). In the reading of these lines, which is unsatisfactory from the contextual point of view - it is not certain on whose behalf the lamella was made, on behalf of a person who would wear it, as said in lines $\mathbf{1 1 + 1}$, or on behalf of a magician who had produced it - Wünsch demonstrates a certain editorial inconsistency. That is, he has the ending -ris in invoc[e]ris $\mathbf{1 3}$ understood as the right spelling where no correction should be noted, contrary to its previous occurrence in opteneris $\mathbf{1 0 / 1 2}$, where he assumed that the correct spelling had not been used and noted in the commentary that the right form was optineres. The other problematic place is the translation of gravedo as "difficulty", since this meaning does not occur in the Latin texts. The word gravedo has two main meanings: that of "illness" (morbus) and that of "weight" (pondus). (The first one is far more frequent and comprises different kinds of illnesses which could afflict the head and stomach, as well as other organs such as the eyes, the kidneys, the breasts, and the chest. ${ }^{6}$ ) And finally, it should be noted that, contrary to all other editors, including Barada, Wünsch has read an abbreviation of sine before the word gravedene (=CL gravedine). In that place, which is very near the lower hole of the tablet, other editors read a sign of a cross. Thus, maybe (mis)led by the reading of a preposition sine where others did not see a word, Wünsch's interpretation of lines 12-13 does not seem satisfactory.

However, his palaeographic solutions of the line 13 s(in)e gravedene invoc[e]ris deserve attention. They differ from the reading of Barada $\dagger$ grandene nuoceres 13 . The first word $s(i n) e$, discussed above, is a sign almost destroyed by the perforated hole, as Wünsch also admitted. For the other word gravedene, Wünsch, contrary to other editors, asserts that "before a letter $d$ can be seen a hook of a ligated $e$ " and that it should be read gravedene, not grandene (=CL grandine). In the edition of Barada and others, it is this very word that had shaped the meaning of the whole tablet, its purpose and function. It is the only word that, if read as it is in modern editions as grandene (hail), gives a rural meaning to the tablet.

${ }^{6}$ ThLL, vol. VI 2, p. 2266, 1.33 - p. $2268,1.12$, s.v. gravedo. 
In their commentary A. and J. Šašel mentioned also silvestria loca and [fulg]ur (their correction in brackets) as other words and phrases which "go well together" with the wilderness of the Dalmatian landscape, thus alluding to the tablet's connection to a (specific) land and its natural characteristics. ${ }^{7}$ Though the phrase silvestria loca - if [fulg]ur is left alone as an editorial conjecture - is a locus communis in exorcistic prayers. Wild, lonely, mountainous places are a realm where the devil or evil spirit is usually banished and they do not allude to any real earthly scenery (cf. loca arida Mt 12:43). ${ }^{8}$ Similar syntagms are to be found in Greek medieval prayers to cure head-

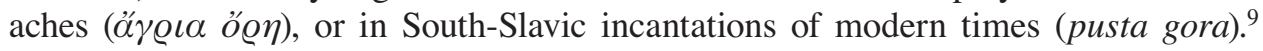
That is to say, the parallels of magical practice can be sought in the texts separated by many centuries, even millennia. ${ }^{10}$ Usually the later ones, which are generally better preserved, can help the reconstruction of the older ones. ${ }^{11}$

Leaving the meaning aside, from a grammatical point of view, the form gravedene/grandene has been specified as AblSg by all editors, who have noted the Vulgar Latin change only on the vocalic level (marked by i/e spelling confusion). Barada, and others, note that grandene stands for classical grandine, Wünsch omits the commentary gravedene $=\mathrm{CL}$ gravedine all together. However, taken absolutely, the form gravedene/grandene can be as much as AccSg as AblSg, since the omission of final $-m$ occurs in all other nouns in AccSg in the text (resurrectione 8, Galilea 9, scriptura 16, fluvio 18, domino 25). In the interpretation of Wünsch, AblSg gravedene was supposed to be governed by the preposition $s($ in)e and in Barada's edition, grandene is understood as the instrumental ablative governed by the verb nuoceres (= CL noceres).

Perhaps neither of these arguments, in their respective editions, may be plausible. In the first case, the opinion of other editors and a half-damaged place where the supposed abbreviation is written, permit a rejection, with a great level of certainty, of Wünsch's $s($ in $) e$ reading. If not governed by a preposition, there is no possible objection to gravedene being read as an accusative, as the final $-m$ of the accusative singular is omitted in the whole text. Even the verb invoc[e]ris which Wünsch read as correctly spelled, and thus in the passive voice, as said above, does not have to be necessarily read in this manner. The previous example of opteneris (=CL optineres) where, according to Wünsch, the spelling confusion i/e in the word's final position occurred, suggests that the same could have happened to the following verb. Thus, its reading should be rather invoc [a]res than invoc[e]ris. If the verb is transitive, the direct object in the accusative is acceptable and the whole phrase, as it is in Wünsch's edition, could be read in its classical form: gravedinem invocares. But, according to Wünsch's trans-

7 ŠAŠEL-ŠAŠEL (n. 2) 383.

${ }^{8}$ MASTROCINQUe (n. 2) 812.

${ }^{9}$ PRADEL, F.: Griechische und süditalienische Gebete, Beschwörungen und Rezepte des Mittelalters. Giessen 1907, 16; РАДЕНковИ下, Љ.: Симболика света у народној магији Јужних Словена [The Symbolism of the World in the Popular Magic among the South Slavs]. Ниш 1996, 50-66.

${ }^{10}$ RADENKOVIĆ, LJ.: Apocryphal Prayers and Apotropaisms among Southern Slavs. Balcanica 28 (1997) 160-161.

${ }^{11}$ KotAnsky, R.: Greek Magical Amulets. The Inscribed Gold, Silver, Copper, and Bronze Lamellae. Vol. I. Opladen 1994, 60. 
lation, the verb invocare in our tablet means "to make incantations, to call the devil for help" while the subject is a magician, sorcier. Could the devil be the subject and the phrase mean "(you [unclean spirit]... should not) invoke an illness by incantation"? Or might a semantic change have taken place and the meaning of invocare here be "cause or provoke", i.e. "(you [unclean spirit]... should not) cause an illness"? The possibility of an active voice invocares in the edition of Wünsch leaves these questions open.

On the other hand, in Barada's edition the ablative case grandene is supposed to be governed, as said above, by the verb nuoceres (= CL noceres) and the phrase is translated as "(I order you [unclean spirit]) to do no harm by hail (to people)". ${ }^{12}$ This is the reading and translation which is accepted in most modern studies. However, the verb nocere has rarely an ablative as complement, with only one occurrence cited in Forcellini's dictionary. ${ }^{13}$ The verb is generally used absolutely, with the dative of the person, or with the direct object in the accusative. As in English for instance, for the verb "do harm", the instrumental case (or prepositional phrase with instrumental meaning) is not its natural complement. Bearing this in mind, Barada's reading nuoceres could be questioned, even more, because it is based on only one letter. The other editors have read $i$ in front of $n$, though Barada was assured that it was not a letter, but a breach on the lead. He added also that it could not be an $i$ because it differed from the other $i$ longa in the text. ${ }^{14}$ And, if the new photographs of the tablet are checked, it can be said that in front of the $n$ there is a line, as long as the other $i$ longa in the text, but not as straightforward as these. Again, as in the case above, a positive answer cannot be given.

\section{SIMILAR OBJECTS AND TEXTS}

The lead tablet from Trogir shares some characteristics with a certain number of ancient and medieval magical objects and texts, which it can be compared with. The categorization and type of most of them is known. In this part, by comparison with similar objects, we shall try to arrive at some more decisive conclusions regarding the purpose and type of our tablet.

Firstly, our tablet has two features which put it in the category of phylacteries, magical objects with protective and apotropaic purposes. There is, on the one hand, the presence of the exorcistic formula denontio (= CL denuntio) tibi addressed to the "unclean spirit", and on the other hand, the presence of three historiolae, small narratives which depict the unclean spirit as defeated in some way.

Before we look for similar objects for comparison, there are some remarks that have to be made. The formula denuntio tibi is not the usual exorcistic formula. In Latin exorcistic prayers this is generally expressed by the verb adiuro followed by an

\footnotetext{
12 BARAdA (n. 2) 16.

${ }^{13}$ ForCELlini, AE.: Lexicon Totius Latinitatis III. Bononiae 1965, 379, s.v. nocere (nociturus pondere Luc. Phars. III 626).

${ }^{14}$ BARADA (n. 2) 13, n. 30.
} 
accusative (adiuro te), the literal translation of the Greek $\varepsilon^{\prime} \xi o \varrho x i \xi \omega \sigma \varepsilon$. Also, the fact that the verb denuntiare is followed by the dative tibi was found by some researchers to be exceptional and aberrant, and they corrected it with an accusative. ${ }^{15}$ It was probably influenced by the French translation "dénoncer" given in the Wünsch's commentary, which emphasizes the meaning of denuntiare accompanied by the accusative. Although the verb with the dative has another meaning, "to order", this would be acceptable in the exorcistic context as well, and no correction need be made. ${ }^{16}$ The Greek verb $\pi \alpha \varrho \alpha \gamma \gamma \varepsilon \dot{\varepsilon} \lambda \lambda \omega$, which is the Greek translation of denuntiare for some of its meanings, can be found, as Mastrocinque pointed out, in the New Testament, in the exorcism of St. Paul (cf. Acts 16:18). ${ }^{17}$ The meaning of the Greek verb in this place, as can be seen in Jerome's translation, is that of praecipere, "to order". Also, in the single occurrence of this verb in the corpus of Latin defixiones - which can be regarded as similar magical objects only with a different purpose - its meaning was the same, "to order", "befehlen". ${ }^{18}$ It could imply, maybe, that the verb denuntiare with the meaning "to order" was a part of the vocabulary of magical practice and was used on magical lamellas, regardless of their purpose. Also, the influence of Greek and the literal translation of $\pi \alpha \varrho \alpha \gamma \gamma \varepsilon \dot{\varepsilon} \lambda \lambda \omega$ cannot be excluded.

If the verb denuntiare on this tablet has the meaning "to order", as Barada also stated in his translation, being a verb in the main clause, the question of the identification of its subordinate clause(s) can be raised. From Barada's translation it can be concluded that it has only one subordinate clause which is ut ne hominebus ... grandene nuoceres. However, this is rather unlikely from the point of view of classical grammar. There is no reason for the sequence of tenses, because of the present tense and the present meaning of the main verb. If some kind of attractio modi with the previous clause ut silvestria loca ... opteneres was not assumed, the verb in the subordinate clause should have been in the present subjunctive. On the contrary, in Wünsch's edition there is a conjuncture incurras or invadas for inar..s $\mathbf{1 1}$ which is the present subjunctive. Although it would form an acceptable sentence, "I order you, unclean spirit ... not to invade people who wear this", because of the fragmentariness of the reading, this should be regarded with caution.

As for the three historiolae, their role, as in other spells, whether Christian or not, is to reinforce the spell and make it more effective. ${ }^{19}$ In exorcistic amulets, this method, known as "persuasive analogy" (persuasio per analogiam), is used to scare the demon and make it flee. In our tablet, where the magician asks the Christian god

15 Mastrocinque (n. 2) 829; Gager, J. G.: Curse Tablets and Binding Spells from the Ancient World. New York 1992, 225.

${ }^{16}$ ThLL, vol. V 1, p. 554, 1. 48 - p. 555, 1. 5, s.v. denuntiare.

${ }^{17}$ Mastrocinque (n. 2) 828.

${ }^{18}$ KROPP, A.: Magische Sprachverwendung in vulgärlateinischen Fluchtafeln (defixiones). Tübingen 2008, 151, n. 622.

${ }^{19}$ VERSNEL, H. S.: The Poetics of the MagicalCharm: An Essay in the Power of Words. In MiRECKI, P. - MeYer, M. (eds.): Magic and Ritual in the Ancient World. Leiden 2002, 122; FrANKFURTER, D.: Narrating Power: The Theory and Practice of the Magical Historiola in Ritual Spells. In MEYER, M. Mirecki, P. (eds.): Ancient Magic and Ritual Power. Leiden 1995, 458. 
for help, this is performed by mentioning the demon's humiliation and defeat in the encounter with Christ and his angel (Gabriel), as well as the barrier that the demon cannot cross (the River Jordan, the river where Christ was baptized).

It is observed that these stories reflect the apocryphal tradition, but their exact sources still remain unknown. The parallels for the first one, where it is said that "the angel Gabriel, who possessed ten thousands of barbar, has bound the unclean spirit of Tartarus with burning fetters", may be traced back to the Testament of Solomon, where it is said that it is the angel Gabriel who can thwart Barsafael, a demon who causes headaches, and that the angel Gabriel can do this by "imprisoning the demon"

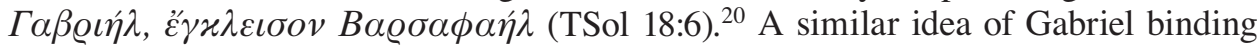
a demon can be found in the Book of Tobit 8:3, in the recension based on Codd. Vat. et Alex., where it is narrated that the angel Gabriel (not Raphael, as it is in Codex Sinaiticus) bound $\varepsilon \delta \eta \sigma \varepsilon v$ the demon Asmodeus. ${ }^{21}$ Maybe a fact in favour of this last hypothesis would be the translation of the same place in the Vulgate, which, although the name of the angel is different, has some similarities with the wording of our tablet tunc Rafahel angelus adprehendit daemonium et religavit eum in deserto superioris Aegypti. ${ }^{22}$ Also, regarding the means by which the unclean spirit was bound in our tablet, as Mastrocinque pointed out, there could be a connection with the apocryphal writings of the New Testament Historiae apostolicae auctore Abdia, where the same idea of burning the fetters by which the demon is bound is present, expressed with the same adjective and the same noun igneis catenis (Abdiae Hist. apostolicae lib. 8. 7. 10). ${ }^{23}$

Maybe the tracing of the exact sources of this narrative has been hindered by different understandings of the relative clause in line 7 qui habet dece $(\mathrm{m})$ milia barbar and of its antecedent. Again it was Wünsch alone who had a different opinion, and only recently that he was followed by Mastrocinque. ${ }^{24}$ Namely, from a grammatical point of view, the antecedent of this relative clause is the angel Gabriel, but very soon after the first edition of the tablet the opposite was argued. According to De Rossi, it was the demon "who possessed ten thousand barbar, evil spirits, snake-headed demons". ${ }^{25}$ Wünsch opposed this "schwerfälliger Wechsel in der Person", noting also that the meaning of the clause would be inadequate - that it would be a kind of glorification of the demon's power. ${ }^{26}$ However, it seems that when Wünsch proposed the solution he had the same idea as other editors of habere, "to have under one's power, to rule": the angel Gabriel ruled, not an army of evil spirits, but a land of barbarians (barbar standing for barbarorum), explaining that Gabriel was perhaps some kind of local deity, "Regionsdämon". Mastrocinque, on the contrary, understood differently not the

${ }^{20}$ McCown, C. C. (ed.): The Testament of Solomon. Leipzig 1922, 52*.

${ }^{21}$ Cited according KotAnsky, R.: Greek Exorcistic Amulets. In MEYER-Mirecki: Ancient Magic (n. 19) 258. However, no name of angel mentioned in Cod. Vat. according to LiTTMAN, R. J.: The Book of Tobit in Codex Sinaiticus. Leiden 2008, 178-179.

${ }^{22}$ Biblia Sacra iuxta Vulgatam Versionem. Eds. R. WEBER - R. GRYSON. Stuttgart 1994, 684.

${ }^{23}$ GILES, J. A.: Codex apocryphus Novi Testamenti, I. London 1852, 419; cf. MASTROCINQUE (n. 2) 829.

${ }^{24}$ MastrocinQue (n. 2) 829.

${ }^{25}$ DE Rossi (n. 2, 1. 2) 40.

${ }^{26}$ WÜNSCH (n. 2) 27. 
word barbar, but the verb habere "to have under one's power, to tame". By this slight change of meaning we might say that the sense of the clause became more probable and more acceptable: "the angel Gabriel, who has tamed (perhaps imprisoned or bound) ten thousand evil spirits [...]". The message would be clear and appropriate to the context: the power is on the side of the angel, he is the one who has already dealt with ten thousand demons and who could easily do the same again.

For the second narrative, where it is said that the unclean spirit, after resurrection, came into Galilea and there encountered Christ, who ordered him to go to mountainous places, no probable sources have been traced. Mastrocinque proposed that the basis for the story could be the passage in the Gospel of Mark, where it is narrated that the Christ's first apparition after the resurrection was to Mary Magdalene, from whom he expelled seven demons (Mk 16:9). ${ }^{27}$ In Wünsch's commentary, apart from it being said that the resurrection happened in Galilea (Mt 28:16), no source is mentioned.

In the third historiola there is a dialogue composed of one question and one answer between the demon and an unknown interlocutor, given in indirect speech. When asked why he could not cross the River Jordan, the unclean spirit replied "because there runs a fire [...]". The continuation of this sentence, if all editions are taken into account, has two main readings: aranea ignifera/ignefera (Detlefsen, Ljubić, Predelli, Barada et al.) and a ganea ignifera (Zangemeister, Wünsch). If the first aranea ignifera/ignefera is correct, it would imply that there were two adjectives accompanying the noun ignis "fire" among which ignifera "fire-bearing" would be pleonastic and redundant. On the other hand, the reading a ganea ignifera, which Zangemeister was the first to propose, could have a more plausible translation and thus perhaps be more probable. For according to Paul the Deacon ganeum (=ganea) means a "hidden place", or "place under the earth" (Paul. Diac. De verb. sign. 96). ${ }^{28}$ Although the current and normal meaning of this word in Classical Latin was "eating-house of bad repute, abode of prostitutes", it appears that the meaning mentioned by Paul the Deacon is the one used by the writer of the tablet. ${ }^{29}$ The demon's answer would be, then: "because there runs a fire from the fire-spitting hole". ${ }^{30}$ As in the previous example, perhaps the (mis)translation of this clause is the reason why the sources of this, the third historiola, still remain unknown.

As for the presence of these abbreviated narratives in magical texts and on specific types of magical objects, it is known that most of the spells with historiolae are those of a medical nature, texts with a therapeutic purpose. ${ }^{31}$ However, the three spells against hail, one from the Byzantine manuscript tradition, and the other found on two objects dated to the $6^{\text {th }}$ and $7^{\text {th }}$ centuries (Furnos Maius - modern Aïn-Fourna, Tunisia) and to the $8^{\text {th }}$ century (Asturias, Spain), show that they can be found in the texts and phylacteries which are regarded as part of rural magical practice. ${ }^{32}$ The same could be said for the exorcistic formula which is found in two of these three spells (the one

\footnotetext{
${ }^{27}$ MastrocinQue (n. 2) 829.

${ }^{28}$ ForCELlini, AE.: Lexicon Totius Latinitatis II. Bononiae 1965, 575, s.v. ganea.

${ }^{29}$ ThLL, vol. VI 2, p. 1689, 11. 77-82, s.v. ganea.

${ }^{30}$ GAGER (n. 15) 225.

${ }^{31}$ FrANKFURTER (n. 19) 461.

${ }^{32}$ Mastrocinque (n. 2) 812-813, 821-826, 831-833; Maltomini (n. 5) 175 no. 13, no. 14.
} 
preserved in the Byzantine manuscript and the other dated to $8^{\text {th }}$ century Spain), then on a spell from the $4^{\text {th }}$ century (?) (Philadelphia, Lydia - modern Alaşehir, Turkey). ${ }^{33}$ And thus, we may remark - while pointing out its general apotropaic purpose - that the mere presence of an exorcistic formula or historiolae in our tablet cannot help with its categorization.

Finally, the tablet's physical characteristics can be taken into account: the material of which it is made and the fact that it is perforated.

The material was not common in phylacteries in Antiquity. Because of its "chthonic" features - being cold and heavy - lead was used rather for "black" magic, in the production of defixiones. ${ }^{34}$ However, the few ancient phylacteries made of lead which are, as Giannobile and Jordan have remarked, all late and all Christian, could not be classified as phylacteries for some specific purpose. ${ }^{35}$ Among them there are spells for general protection, for protection against illness, but also those for the protection of crops and agricultural property (the last ones are three in total).

Thus, the conclusion would be the same as above. Taking this feature into account cannot lead to any specification of the tablet.

The last feature we are going to analyse is the fact that the tablet is perforated. It has two holes on the left edge. The upper measures $3 \mathrm{~mm}$ in diameter, the lower one $4 \mathrm{~mm}$ in diameter. ${ }^{36}$ As may be remarked, the perforation of phylacteries was not common. As for the phylacteries for individual protection (amulets), they themselves were not usually perforated, but rather the capsules into which they were put. As for the phylacteries against hail, their perforation is rather rare. There are two examples: the lead cross from Furnos Maius which has three holes on its vertical part and a bronze phylactery from Bouchet (France) with a hole in its centre. ${ }^{37}$ It is the general opinion that the first ones, amulets, were worn around the body - first rolled up and then put into the suspended capsules. For the phylacteries against hail, it is thought that the holes were used for affixing them to some kind of support, maybe stone. Taking into account their obvious rural purpose, the protection of crops (Bouchet), vineyards, olive trees, gardens (Furnos Maius), they were probably affixed somewhere outdoors. As might be expected and as is also known from some examples which explicitly name their locations e.g. "to be put in three corners of the property", the phylacteries against hail were usually placed near the object(s) they were supposed to protect. ${ }^{38}$ If the same should be assumed for our tablet, that it was affixed outdoors, the position of its holes would imply that, for making it stable on the supporting object, the tablet (and the text) should be turned horizontally. Although, of course, that could have been the case - the

${ }^{33}$ Mastrocinque (n. 2) 819-820; Maltomini (n. 5) 176, no. 17.

${ }^{34}$ GAGER (n. 15) 4.

${ }^{35}$ Giannobile, S. - JoRdan, D. R.: A Lead Phylactery from Colle san Basilio (Sicily). Greek, Roman, and Byzantine Studies 46 (2006) 75.

${ }^{36}$ Measured by I. Radman and N. Gostinski from the Archaeological Museum of Zagreb.

${ }^{37}$ MALTOMini (n. 5) 174, no. 11; KotANSKY: Greek Magical Amulets (n. 11) 46-47, no. 11.

${ }^{38}$ For the place where rural phylacteries were placed and for examples, see MALTOMINI (n. 5) 160, n. 11; BevilacQua, G. - Giannobile, S.: "Magia" rurale siciliana: iscrizioni di Noto e Modica. Zeitschrift für Papyrologie und Epigraphik 133 (2000) 136-137, 143. 
one who was in charge of affixing it did not need to pay attention to the position of the text nor perhaps even know what its position should be, we should take into account the other possibility - that the tablet was suspended and that the holes were used to put a thread through. In that case, considering the dimensions of the holes, it may be noted that the thread must have been rather tiny and that its durability in outdoor conditions was questionable. Or was the tablet worn as a kind of personal amulet around the neck, as Wünsch had assumed?

\section{CONCLUSION}

Taking into account the possibility of the reading gravedene (illness) in Wünsch's edition, then some grammatical issues in Barada's edition, which emphasise the reading grandene (hail), and finally the physical characteristics of the tablet, we may conclude that we are rather of Wünsch's opinion: the lead tablet from Trogir was not a phylactery against hail, but an exorcistic amulet either for general protection or for protection against an illness called gravedo.

\footnotetext{
Dragana Kunčer

Institute of History

Knez Mihailova 36/II

Belgrade
} 


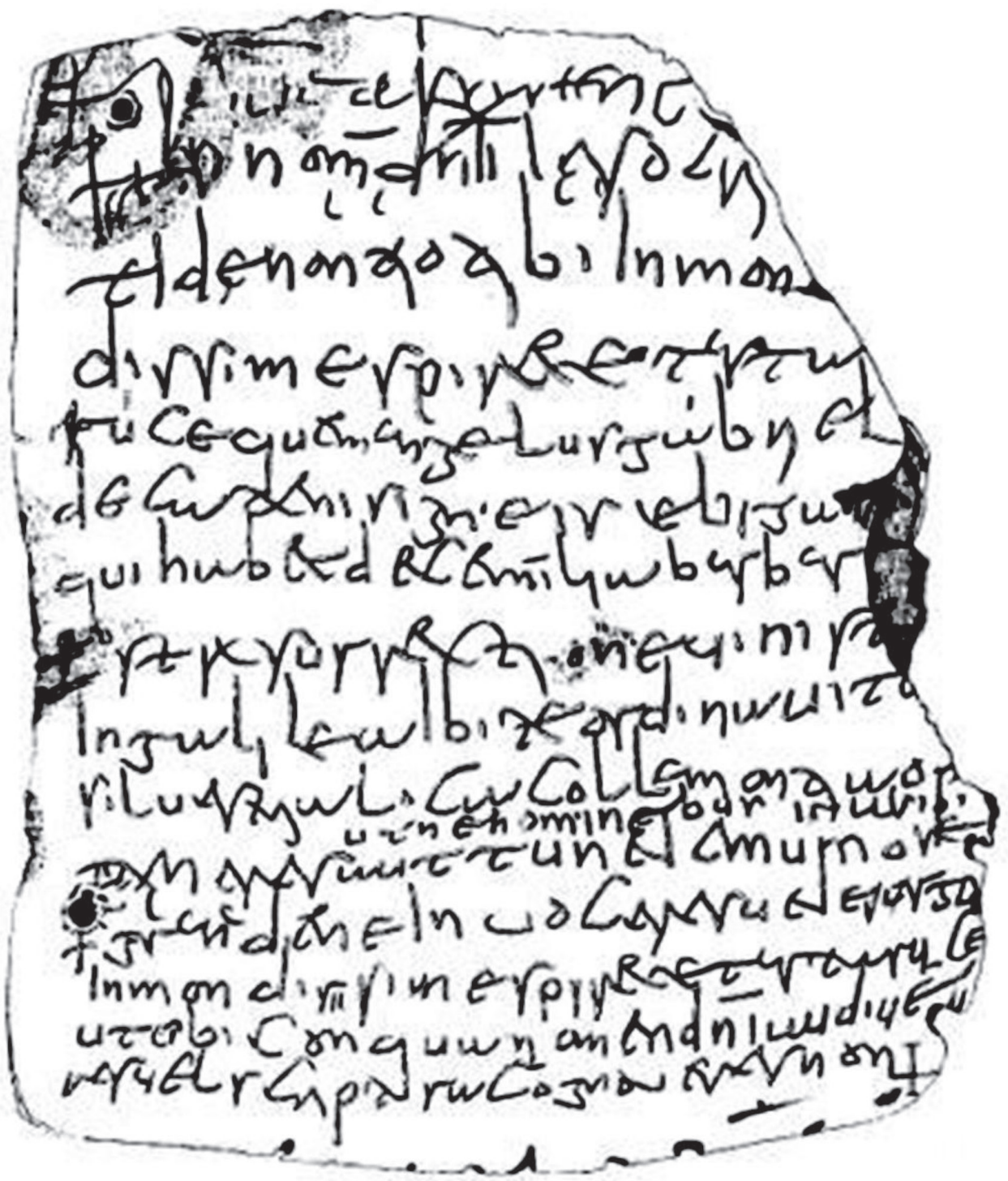

Side A 


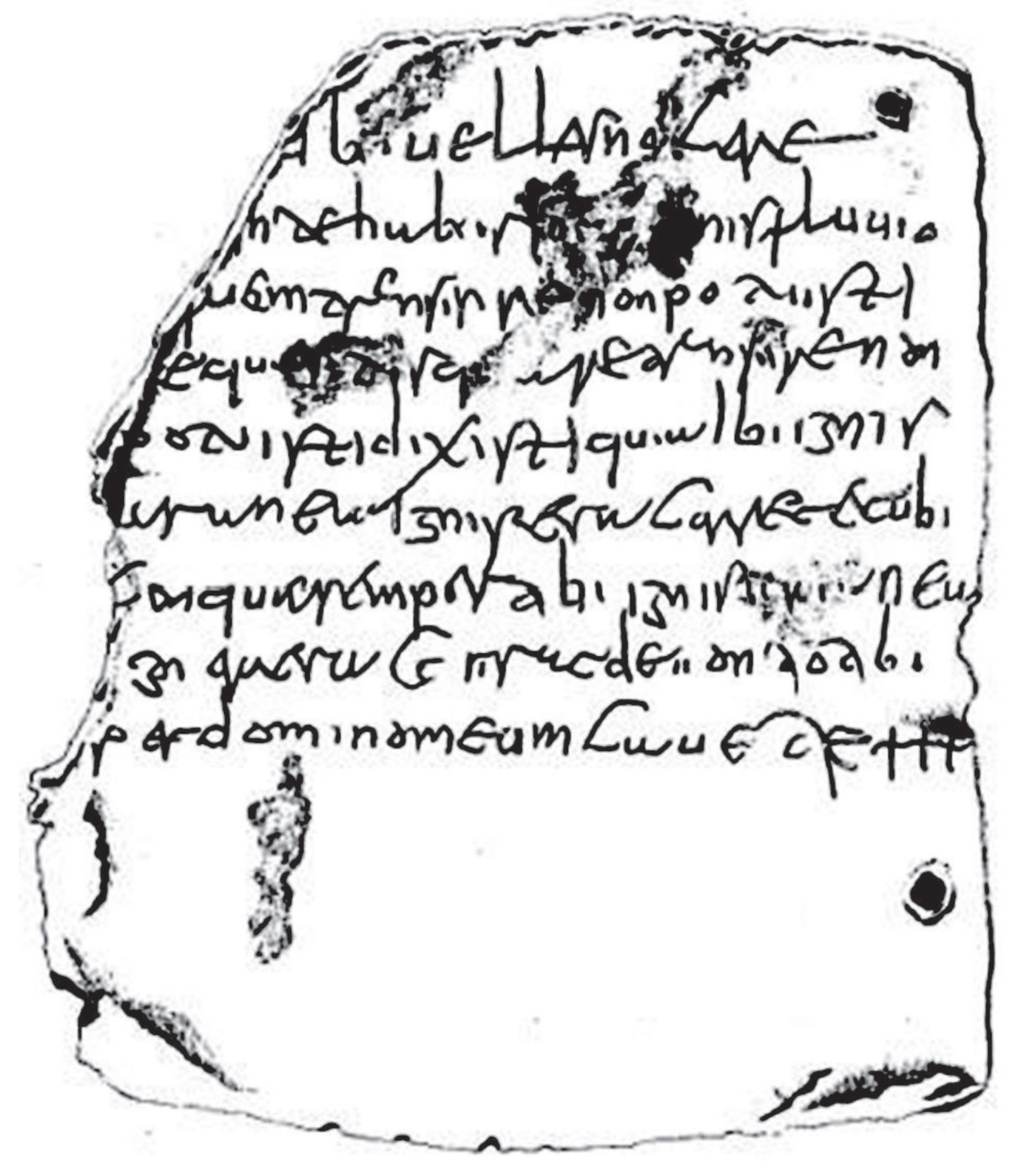

Side B

Drawing by K. Zangemeister, published in CIL III p. 961 (1873) 


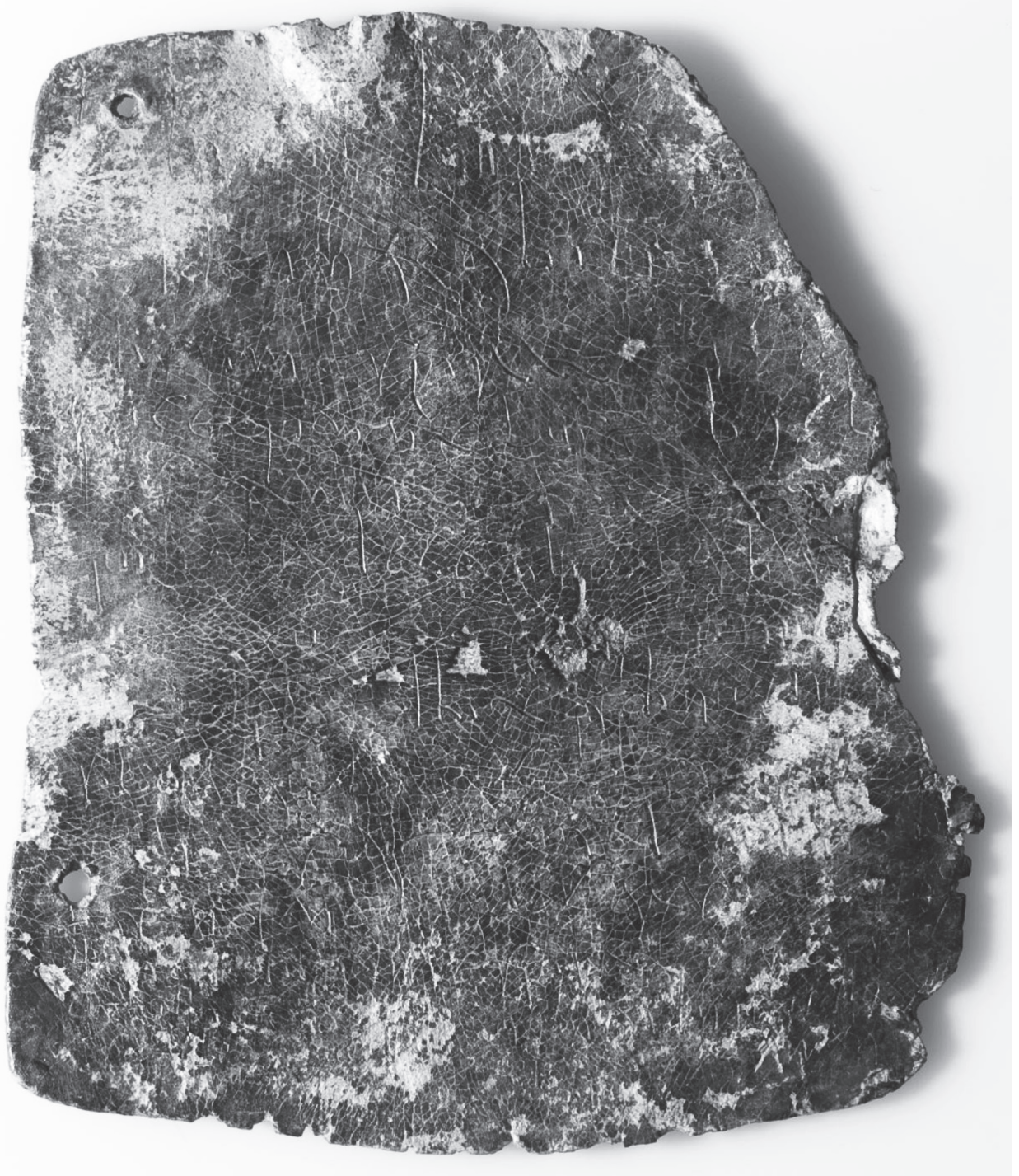

Side A 


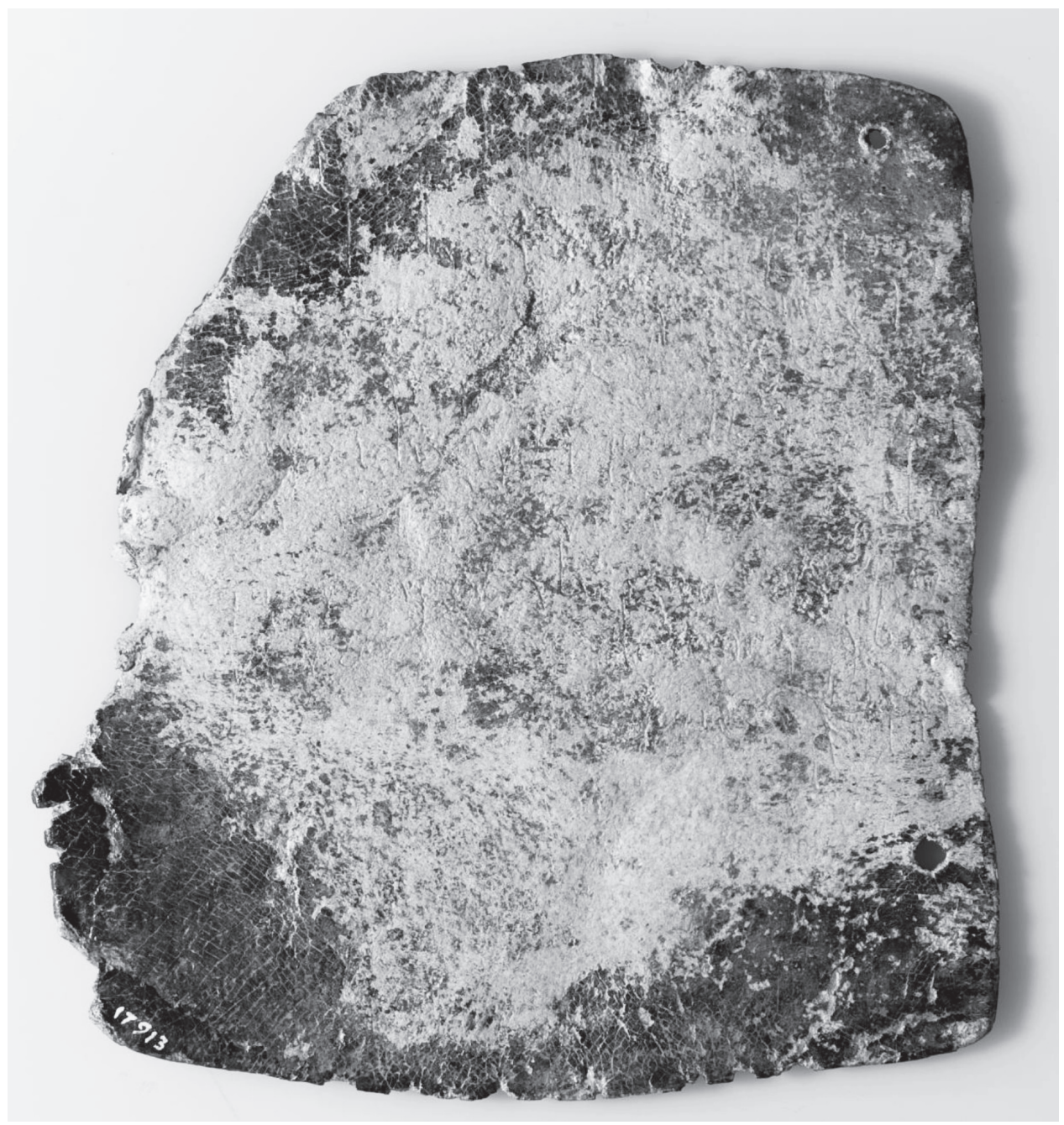

Side B

Photographs by I. Krajcar, Archaeological Museum of Zagreb (2016) 